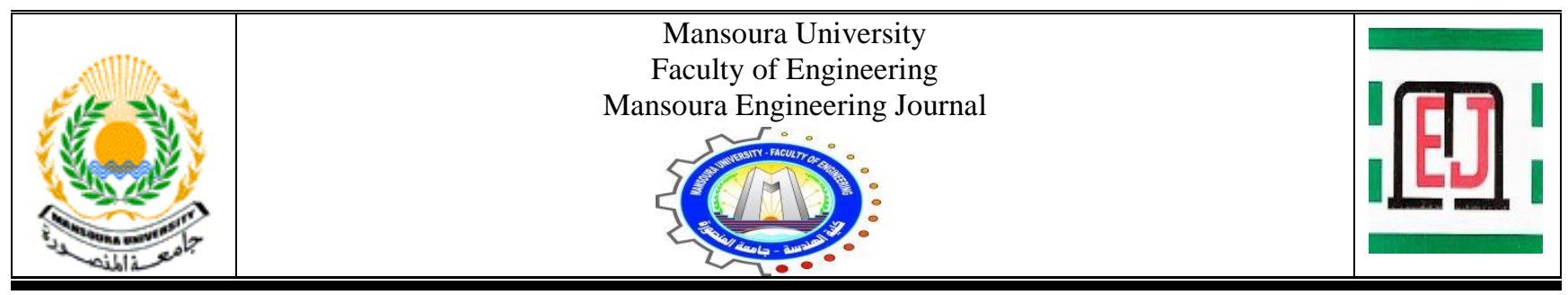

\title{
Economical and Experimental Study of Hybrid Power System of Compressed Air Energy Storage with Photovoltaic Array and Wind Turbine Generator
}

Eid A. Gouda*, Ahmed Abd-Alaziz and Magdi El-Saadawi

\begin{tabular}{|l|}
\hline KEYWORDS: \\
Compressed Air Energy \\
Storage (CAES), Wind \\
Turbine Generator, \\
Photovoltaic (PV) Array, \\
Experimental Hybrid \\
System Prototype, \\
Egyptian Village Case \\
Study, Economic \\
Analysis. \\
\\
\end{tabular}

Abstract-This paper presents an economical and experimental study of large
and small scales Compressed Air Energy Storage (CAES) integrated with PV array
and wind turbine generator based on economic criteria. Two different CAES
systems with three different case studies are presented in detail. The first model
included wind turbine, compressor, and storage reservoir with different rating
values, $220 \mathrm{MW}, 200 \mathrm{MW}$, and $150,000 \mathrm{~m}$ for the turbine, compressor, and storage
reservoir volume respectively. A small CAES power system consists of $5 \mathrm{KW}$
isolated load fed by Bergey Excel-S $10 \mathrm{KW}$ wind turbine is chosen as another
application to investigate the effectiveness of the proposed presented model. The
second presented model is based on real prototype testing and laboratory
measurements supplied from a PV panel. A prototype model is built up in a small
size to indicate the system characteristics and its main effective parameters.
Furthermore, a case study on an isolated Egyptian village (Halayeb) is introduced
as a third case study based on the basics of the proposed prototype system. The
results prove the ability of the CAES system to supply domestic loads of a grid
isolated village. Finally, the paper presented an economic analysis of the presented
system.

\section{INTRODUCTION}

$\mathrm{E}$ LECTRICAL Energy Storage (EES) is a promising option for future utility grids. It can supply more flexible and balanced energy to the grid; it can also improve electrical network management.

Received: (21 May, 2021) - Revised: (19 June, 2021) - Accepted: (23 June, 2021)

*Corresponding Author: Eid Abdelbaki Gouda, associate professor at Electrical Engineering Department, Faculty of Engineering, Mansoura University, (email: eaidgoda@mans.edu.eg.)

Ahmed Abd-Alaziz, is with Electrical Engineering Department, Faculty of Engineering, Mansoura University, (email: aaabdalaziz91@gmail.com .)

Magdi El-Saadawi, professor at Electrical Engineering Department, Faculty of Engineering, Mansoura University, (email: m_saadawi@mans.edu.eg)
Moreover, EES systems can reduce costs, improve efficiency and provide a backup resource of renewable energy systems. In this paper, Compressed Air Energy Storage (CAES) is explored as a large-scale EES that can be designed for a high amount of energy at a high rate. The CAES is based on converting energy into a pneumatic type in pressure vessels or caverns, which are used to regenerate electricity whenever it is required. CAES system is not only friendly to the environment but it also has low maintenance cost [1:4]. For instance, a partial electrical blackout occurred in Egypt in the summer of 2010 and a large part of the grid was out of service for many hours [5]. A large-scale size CAES can be used to help in passing such problems and similar cases.

The first CASE plant was built up in Huntorf (Germany) in 1978 with a capacity of 321 MW over 2 hours. Another plant is McIntosh Alabama (USA) with a rating of $110 \mathrm{MW}$ over 26 hours of continuous operation since 1991 [6]. CAES devices 
can be classified based on the energy conversion type into adiabatic and diabatic. The first CAES plant was a diabatic one depending on making the energy conversion isothermally. The adiabatic type depends on isolating the plant and making a closed-loop energy conversion [6].

Several models and methods to assess CAES were introduced in the last few years [7:17]. In [7] Sciacovelli presented a CAES thermal model with detailed analysis and economic studies. Ibrahim et al. [8] investigated various types of storage methods and discussed their basic characteristics, techniques, and applications. Among these storage techniques, the authors discussed the CAES and gave brief notes about its cost estimation, efficiency, advantages, and drawbacks. Rogers et. al. [9] examined the new trends in CAES, besides they offered an economic analysis for studying the possibility of their low-cost applications. Kleiser et al. [10] described the basics of thermodynamic in CAES and presented in detail a simulation model for studying their performances. The authors presented a proposed model as a dynamic one for a smallscale industrial application. At the side of the microgrids, Ibrahim et al. [11] introduced an article to discuss the combination of the CAES with wind energy in microgrid applications. A wide range of papers on CAES modeling was presented [12:17]. Raju et. al. [12] modeled and simulated CAES in caverns and applied a case study on Huntorf plant, they presented an accurate model for adiabatic and isothermal cases. Greenblatt et al. [13] presented a competition modeling between gas turbines and CAES. Hartmann et al. [14] discussed the CAES efficiency parameters and the affecting factors by simulating and analyzing different adiabatic CAES plants. Bitaraf et al. [15] proposed a technique for reducing curtailed wind energy through energy storage systems such as large CAES. Isobaric Adiabatic CAES was the last modeling development to store the energy by a more efficient method. The model was based on a principle proposed by Chen et al. in 2018 [16]. Mazloum et. al. [17] modeled a dynamic Isobaric Adiabatic CAES with medium system efficiency (53.6\%) and fast response.

On the other hand, hybrid systems have been studied by many researchers [18:22]. A small-scale turbine and compressed air hybrid system are proposed by Krupke et. al. [18], they were used to provide a good profile output power with minimum ripples. Rownak et. al. [19] derived a solar biomass CAES for providing electricity to isolated loads. Cazzaniga et. al. [20] presented an integration between the isothermal CAES system and floating PV plant, the system assured high storage efficiency. Joong-kyoo et. al. [21] analyzed a liquid piston compressor system to the ocean CAES. W. He et. al. [22] presented an adiabatic CAES model integrated with packed bed thermal storage and they implemented the model on system prototypes.

The applications of CAES systems for small or large systems were discussed in [23-24] and the authors presented different ways of CAES applications. Calero et al. presented a simplified version and mathematical model of the diabatic small-scale CAES system [25]. It is found that in the case of using small-scale CAES the suitable and efficient control strategies should build on using bidirectional converters, or multilevel control strategies [26].

$\mathrm{Li}$ et al. designed a large-scale version of CAES and compared the results with real cases and other published works [27]. Speed control based on fuzzy logic controller integrated with CAES system was presented in detail in [28]. King et al. examined new large-scale CAES projects and found updated techniques of store air at higher pressure levels in different reservoir topographies [29]. CHEN et al. studied how to optimize and operate integrated and complex systems with efficient strategies connected with a combined cooling, heating, and power system based on adiabatic compressed air energy storage. The presented technique provided combined cooling, heating, and power-based CAES system with efficient optimal operation [30]. Combined heat and CAES attached with organic Rankine cycle system was modeled, analyzed, and discussed in detail by Wang al. [31].

In conclusion, it can be stated that the CAESs can be considered as important and promising EES devices to support standalone loads and grid applications.

This paper presents a study and analysis about modeling and experimental implementation of large and small scales Compressed Air Energy Storage (CAES) integrated with PV and wind turbine systems based on economic criteria. Two different CAES systems with three different case studies are presented in detail. The paper is divided into five sections. The paper's introduction is presented in the first section. CAES first model description, equations, and operation and two case studies are discussed in detail in the second section. A laboratory-scale CAES system model is derived in the third section. System sizing and economic study of an isolated village are discussed in the fourth section. Finally, the paper ends with the conclusions.

The contributions of this paper are:

* Two new different models of the CAES system are proposed.

* The first proposed model includes a wind turbine, compressor, and storage reservoir with different rating values is simulated efficiently in a dynamic model.

* The effectiveness of the first model is investigated by simulating a small CAES integrated with a $5 \mathrm{KW}$ isolated load fed by Bergey Excel-S $10 \mathrm{~kW}$ wind turbine.

* The second proposed model is based on real prototype testing and laboratory measurement supplied by a PV panel available in the Energy Lab at the Faculty of Engineering, Mansoura University.

* A case study on an isolated Egyptian village (Halayeb village) is applied as a third case study based on the basics of the proposed prototype hybrid system.

* System sizing and economic study of the isolated village are presented.

* The two presented models can be applied for any given power system with any CAES size (small or large).

\section{FIRST PROPOSED CAES MODEL}

CAES system includes electric source subsystem, compression subsystem, air storage, air motor, and generation unit connected to a load. CAES theory of operation depends on converting the excess energy to a pneumatic form in pressure tanks or underground caverns and by using a 
compressor gas turbine unit for the regeneration process of the transmitted energy [32].

\section{A. System Description}

Figure 1 shows a schematic diagram of the main components of the proposed hybrid electrical power system integrated with CAES.

The compression process leads to generate heat; this heat should be removed before storing. The heat energy is stored for later use (Adiabatic process) or be released to air without heat storage (Diabatic process). In a gas turbine plant, about $66 \%$ of the power is required for the process of compressing the air, so it can be pre-compressed in off-peak to be used during peak hours [33]. The storage tanks can be classified into natural storage tanks such as salt domes, cavities in rock formations and aquifers, and artificial storage tanks like metal or concrete housing tanks [33].

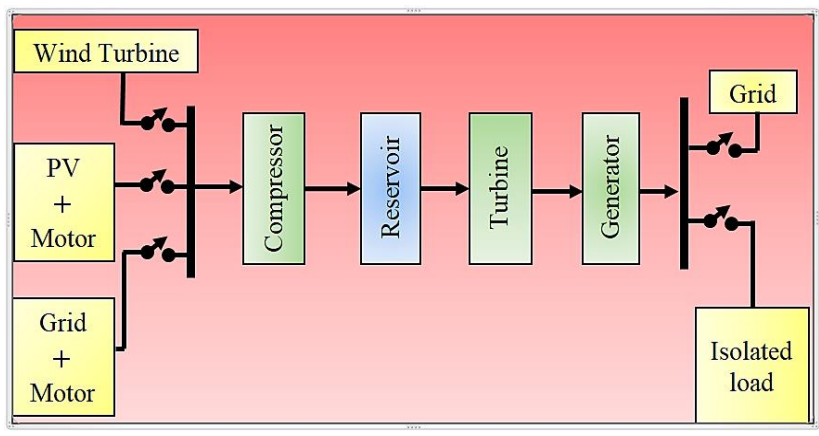

Fig. 1. Schematic diagram of the main components of the proposed hybrid electrical power system integrated with CAES

\section{B. Mathematical Modeling}

This model is based on the following assumptions:

- The process is isentropic with no heat added or temperatures change,

- The gas is ideal with constant specific heat,

- The ratio of fuel to air during the operation inside the turbine is constant, and

- The compressor compresses the air at atmospheric pressure to the reservoir pressure.

The input reservoir air mass flow rate is calculated by the following equations [34, 35]:

$$
\begin{aligned}
& \dot{Q_{l n}}=\frac{W_{c}}{C_{p 1} T_{i n}\left[\left(\frac{P_{2}}{P_{1}}\right)^{\frac{\gamma-1}{\gamma}}-1\right]} \\
& \gamma=\frac{\mathrm{C}_{\mathrm{p} 1}}{\mathrm{C}_{\mathrm{V} 1}}
\end{aligned}
$$

where $\mathrm{W}_{\mathrm{c}}, \mathrm{C}_{\mathrm{p} 1}, \mathrm{C}_{\mathrm{V} 1}, \mathrm{P}_{2}, \mathrm{P}_{1}$, and $\mathrm{T}_{\mathrm{in}}$ are the input compressor power, specific heat at constant pressure, specific heat at constant volume, output compressor pressure, input compressor pressure, and input compressor temperature respectively.

An air turbine of double stages is used to transform the potential stored energy in the reservoir to mechanical energy during the discharging process where the discharging rate equation is expressed as $[23,35]$ :

$$
\begin{array}{r}
\mathrm{Q}_{\text {out }}^{\cdot}=\frac{\mathrm{W}_{\mathrm{G}}}{0.3326 \mathrm{C}_{\mathrm{p} 2} \mathrm{~T}_{2}\left[1+\frac{\mathrm{Q}_{\text {out }}^{\cdot}}{\mathrm{Q}_{\text {Fuel }}}\right]} \times \\
\left\{\frac{1}{\left\{\frac{\mathrm{C}_{\mathrm{p} 1} \mathrm{~T}_{1}}{\mathrm{C}_{\mathrm{p} 2} \mathrm{~T}_{2}}\left[1-\left[\frac{\mathrm{Pr}_{2}}{\mathrm{Pr}_{1}}\right]^{\frac{\mathrm{k}_{1}-1}{\mathrm{k}_{1}}}\right]+1-\left[\frac{\mathrm{P}_{\mathrm{b}}}{\mathrm{Pr}_{2}}\right]^{\frac{\mathrm{k}_{1}-1}{\mathrm{k}_{1}}}\right\}}\right.
\end{array}
$$

where, $\mathrm{W}_{\mathrm{G}}, \mathrm{T}_{1}, \mathrm{~T}_{2}, \mathrm{Pr}_{2}, \mathrm{Pr}_{1}, \mathrm{P}_{\mathrm{b}}$, and $\frac{\mathrm{Q}_{\text {out }}}{\mathrm{Q}_{\mathrm{Fuel}}}$, are the generated power of the generator, the input temperature to the highpressure turbine, the input temperature to the low-pressure turbine, the atmospheric pressure, and the ratio of the flow rate of discharging air to turbine fuel respectively.

During the charging and discharging process, the tank pressure should be varied safely between the maximum and minimum limits by which the tank or the reservoir material can withstand without any damage. The air tank mass and pressure are given by $[35,36]$ :

$$
\begin{aligned}
& Q_{\text {tank }}=\int \dot{Q_{\text {In }}} \mathrm{dt}-\int \mathrm{Q}_{\text {out }} \mathrm{dt} \\
& \operatorname{Pr}_{\text {tank }}=\frac{\mathrm{R}_{\mathrm{g}}}{\mathrm{V}_{\text {tank }}}\left(\int \dot{\mathrm{Q}_{\mathrm{nn}}} \mathrm{T}_{\text {inTank }} \mathrm{dt}-\int \mathrm{Q}_{\text {out }} \mathrm{T}_{\text {outTank }} \mathrm{dt}\right)
\end{aligned}
$$

where $R_{g}, V_{\text {tank }}, T_{\text {inTank }}$, and $T_{\text {outTank }}$, are the general gas constant, tank volume, tank input temperature, and tank output temperature, respectively.

\section{Operation and cases studies}

It is known that the stored energy of the CAES is limited by reservoir pressure and mass. The charging and discharging modes depend on the maximum and minimum pressure limits. So the charging and discharging processes should be terminated when the pressure tank reaches to the maximum and minimum values, respectively. The time of charging or discharging is related to the compressor rating, turbine rating, and tank volume. The flowchart of the model procedures is shown in Figure 2.

\section{1) Case study 1: $220 \mathrm{MW}$}

The aforementioned model can be applied for studying and analyzing any given power system integrated with the storage system. In this section, the model is adapted for a system combined with an isolated load fed by a wind turbine without a PV array. All the required design data and power curves including the wind power $W_{i n}$, the demand load power $W_{d}$ and the other missed data are given in [35]. The rating of CAES systems should be chosen according to the average power value during one year for maximum actual available wind power $W_{\text {in }}$ and the demand load power $W_{d}$. So the selected suitable rating values are about $220 \mathrm{MW}, 200 \mathrm{MW}$, and $150,000 \mathrm{~m}^{3}$ for the turbine, compressor, and storage reservoir volume respectively [35]. A Matlab simulation program is built to represent the CAES system based on the data given in Table I and the flowchart is given in Figure 2. The program is implemented for one week and results are shown in Figures 3 and 4. The results include the variations of the input wind power, demand load, compressor power, and reservoir input flow rate generated power, reservoir flow rate 
output, reservoir mass, and reservoir pressure during the simulation period.

From the obtained results, it is observed that CAES cannot be able to feed the demand load for all the prescribed periods due to the constraints of reservoir pressure limits. When the pressure tank reaches the lower limit (15 bar) the generation process must stop $\left(\mathrm{W}_{\mathrm{G}}=0\right)$ this occurs on day 3 . It is worth mention that the reservoir was empty on the first day, so it is incapable to feed the load before the charging process.

\section{2) Case study 2: $10 \mathrm{KW}$}

In this case study, a small CAES power system consists of $5 \mathrm{KW}$ isolated load fed by Bergey Excel-S $10 \mathrm{~kW}$ wind turbine [38] is chosen as another application to examine the effectiveness of the proposed model.

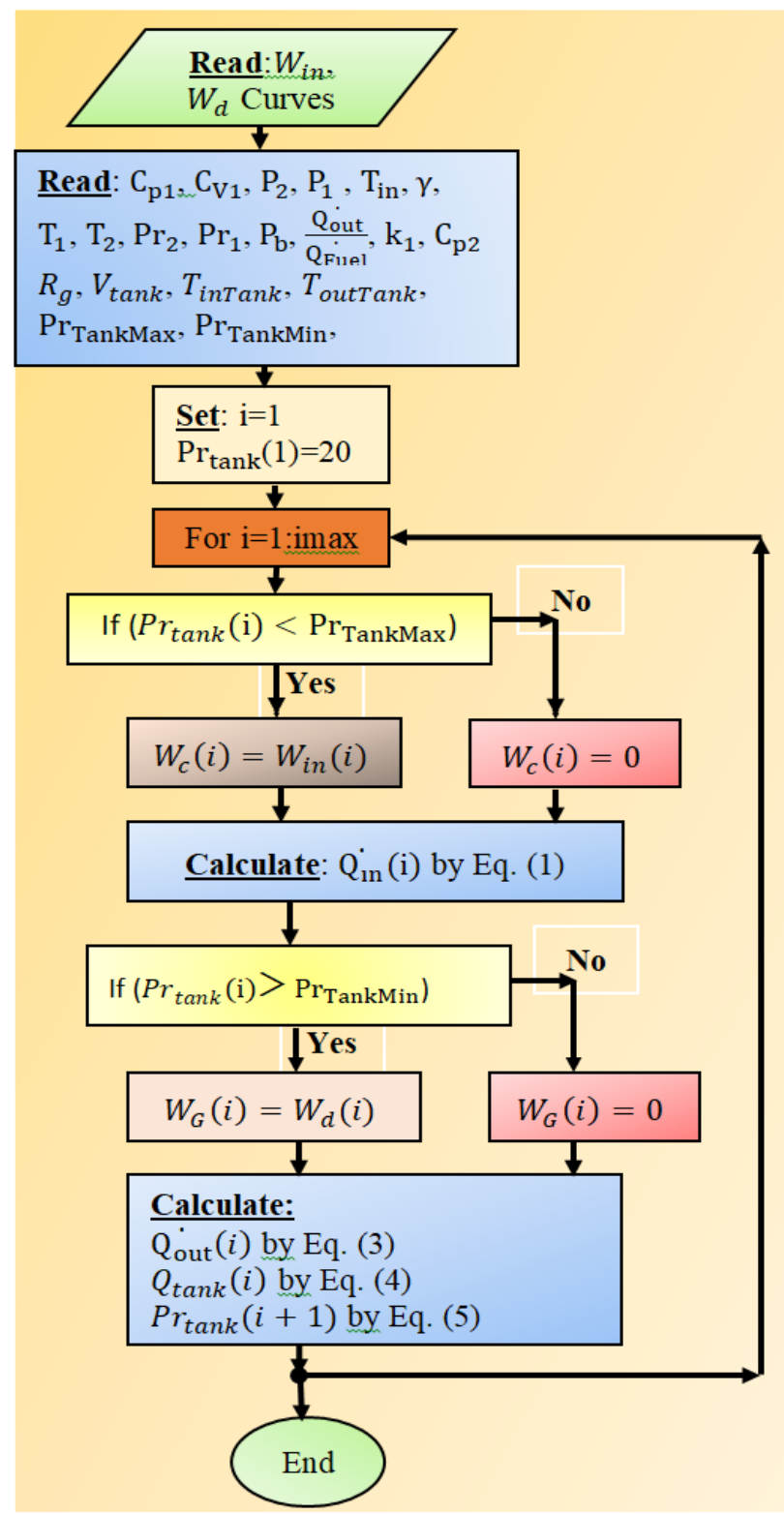

Fig. 2. Flowchart of the procedures of the first proposed model
In this case study, the proposed program is implemented on a minute time scale for a single-day study. The same input data mentioned in the previous case study is used (Table I). Depending on the peak value of the demand load and the input power, the appropriately selected rating values of the CAES components are about $10 \mathrm{KW}, 10 \mathrm{KW}$, and $5 \mathrm{~m}^{3}$ for the turbine, compressor, and storage reservoir volume respectively. The maximum and minimum reservoir pressures are proposed to be 5 bar and 1.5 bar. All the results are depicted in Figures 5 and 6.

TABLE I

CONSTANTS AND INPUT REQUIRED DATA [35, 36, 37]

\begin{tabular}{c||l||l}
\multicolumn{1}{c||}{ Constants } & \multicolumn{1}{c}{ Value } & \multicolumn{1}{c}{ Unit } \\
\hline$C_{p 1}$ & 1.055 & $\mathrm{~kJ} / \mathrm{kg} \mathrm{K}$ \\
\hline$C_{p 2}$ & 1.009 & $\mathrm{~kJ} / \mathrm{kg} \mathrm{K}$ \\
\hline$P_{2} / P_{1}$ & 69 & -- \\
\hline$T_{\text {in }}$ & 298.15 & $\mathrm{~K}$ \\
\hline$\gamma$ & 1.3 & \\
\hline$T_{1}$ & 823.15 & $\mathrm{~K}$ \\
\hline$T_{2}$ & 1098.15 & $\mathrm{~K}$ \\
\hline$P r_{2}$ & 42 & $\mathrm{bar}$ \\
\hline$P r_{1}$ & 11 & $\mathrm{bar}$ \\
\hline$P_{b}$ & 1 & $\mathrm{bar}$ \\
\hline$Q_{\text {out }}$ & 0.25 & - \\
\hline$Q_{\text {Fuel }}$ & & \\
\hline$k_{1}$ & 1.3 & $\mathrm{~J}$ \\
\hline$R_{g}$ & 287.058 & $\mathrm{~J} / \mathrm{kg} \mathrm{K}$ \\
\hline$V_{\text {tank }}$ & 150000 & $\mathrm{~m}{ }^{3}$ \\
\hline$T_{\text {inTank }}$ & 298.15 & $\mathrm{~K}$ \\
\hline$T_{\text {outTank }}$ & 298.15 & $\mathrm{~K}$ \\
\hline$P r_{\text {TankMax }}$ & 70 & $\mathrm{bar}$ \\
\hline $\operatorname{Pr}_{\text {TankMin }}$ & 15 &
\end{tabular}

From the obtained results, it can be seen that when the tank pressure reaches the upper limit of 5 bar the controller disconnects the compressor and reconnects it again when the pressure decreases. This process repeated many times [at 330 to $360 \mathrm{~min}$ ], and [at 450 to $540 \mathrm{~min}$ ]. The same procedure will occur when the pressure arrives at the lower limit of 1.5 bar, the generator will be connected and reconnected again if the pressure increased again as found at 920 to $1440 \mathrm{~min}$.

\section{LABORATORY-SCALE CAES SYSTEM (2ND MODEL)}

The objective of this section is to build a CAES model based on real prototype testing and laboratory measurement. The system under consideration is a small diabatic CAES system consists of a PV array, a dc compressor, a storage tank, an air motor, a dc generator, and a resistive lamp as shown in Figure 7. The function of the proposed system is to store the excess energy generated from the PV system in a pneumatic air storage tank, and then convert the stored energy to rotational kinetic energy to generate electricity to supply the load whenever is required. 


\section{A. System description}

To charge the proposed storage system, a PV system with a rating of about $100 \mathrm{~W}, 12 \mathrm{~V}$ is required to feed the compressor, so a Monocrystalline solar panel with $100 \mathrm{~W}, 12$ $\mathrm{V}$ was selected [39] where its IV and Power Characteristic curves are presented in Figure 8. The compressor characteristics should have a low speed reciprocating, 0.9 efficiency $100 \mathrm{~W}$ and $12 \mathrm{~V}$. The time expected for the charging process will be about one min based on the used compressor characteristics [40]. A cylindrical metal tank is used as a small reservoir, with a volume of $\mathrm{V}=0.00454 \mathrm{~m}^{3}$, to store the compressed air with allowable different pressure levels of 6.5 bar.
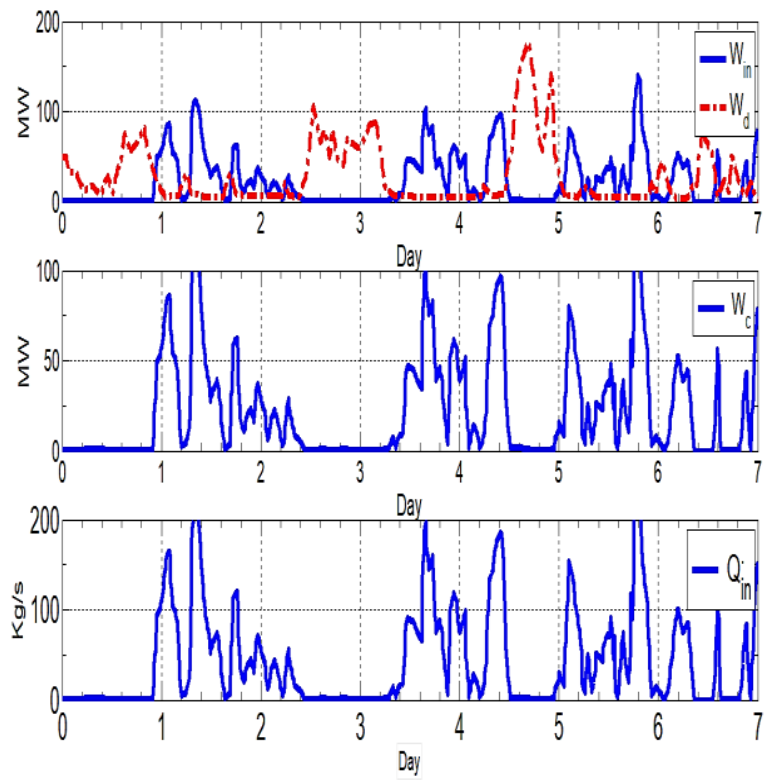

Fig. 3. Input wind power, demand load power, compressor power, reservoir input flow rate (220 MW CAES case study)
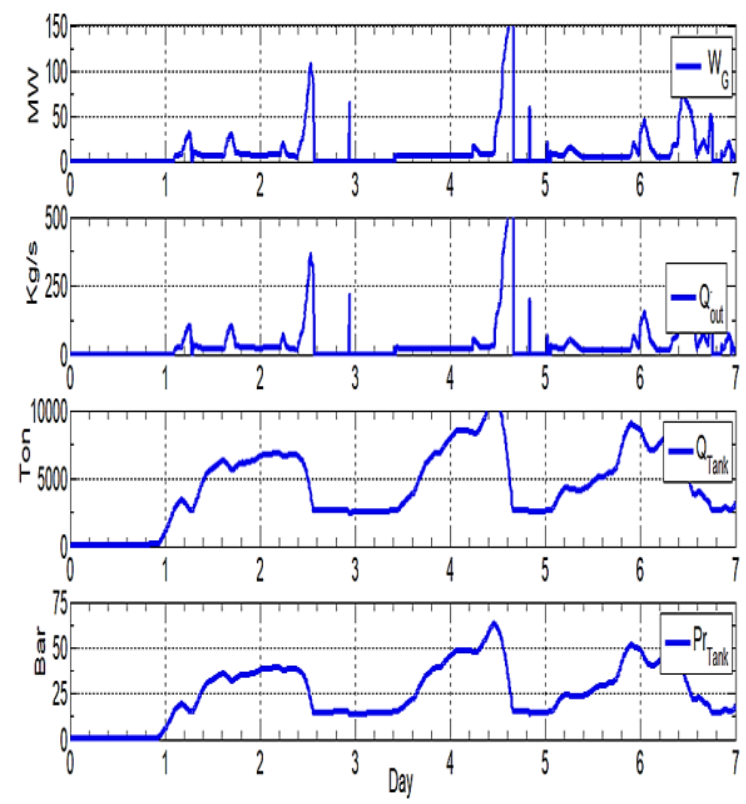

Fig. 4. Generated power, reservoir flow rate output, reservoir mass, reservoir pressure(220 MW CAES case study)
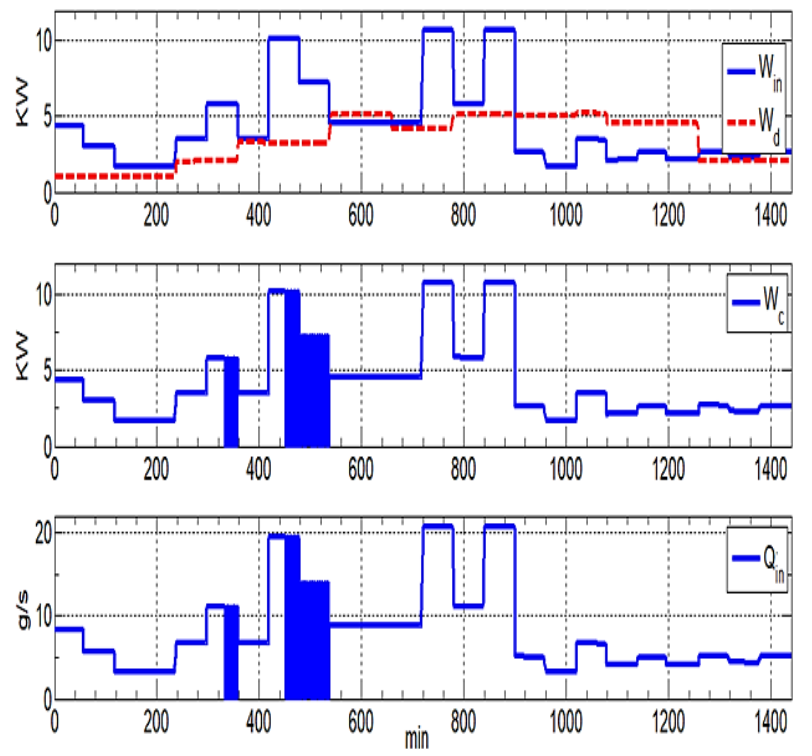

Fig.5. Input wind power, demand load power, compressor power, reservoir input flow rate (10 KW CAES case study)
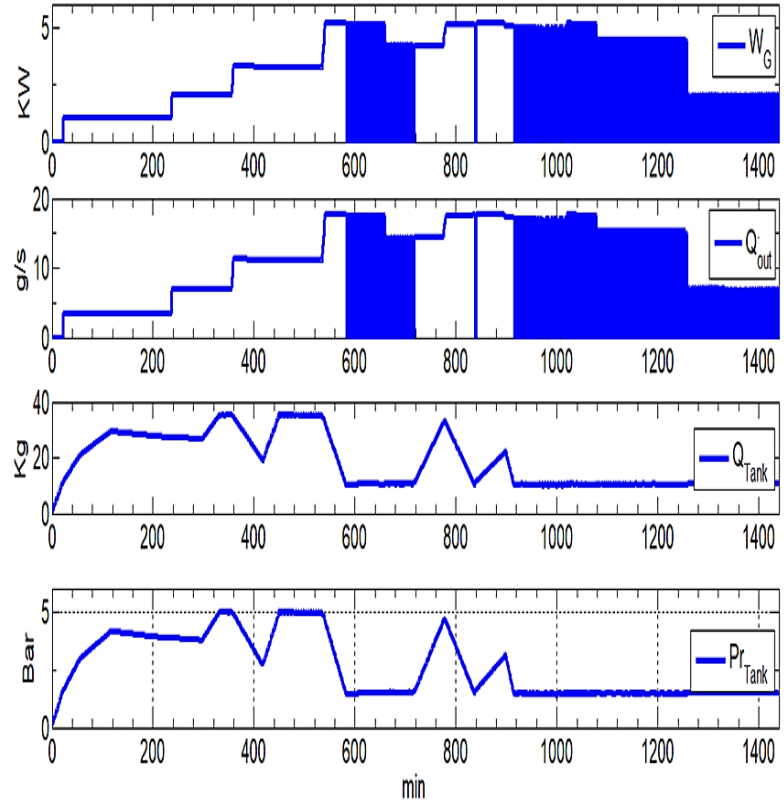

Fig.6. Generated power, reservoir flow rate output, reservoir mass, reservoir pressure(10 KW CAES case study)

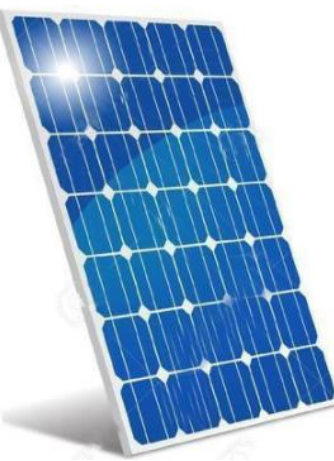

a) PV panel

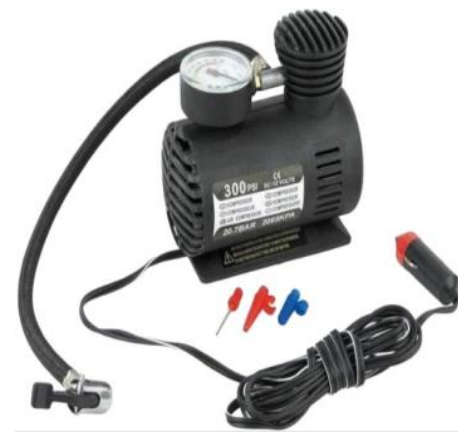

b)-dc compressor 


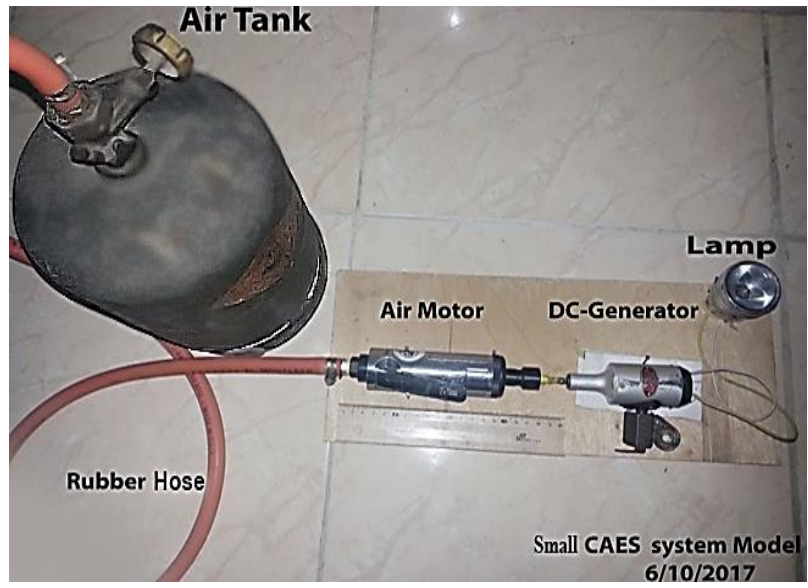

c)proposed prototype

Fig.7. Components of the proposed small-scale CAES prototype

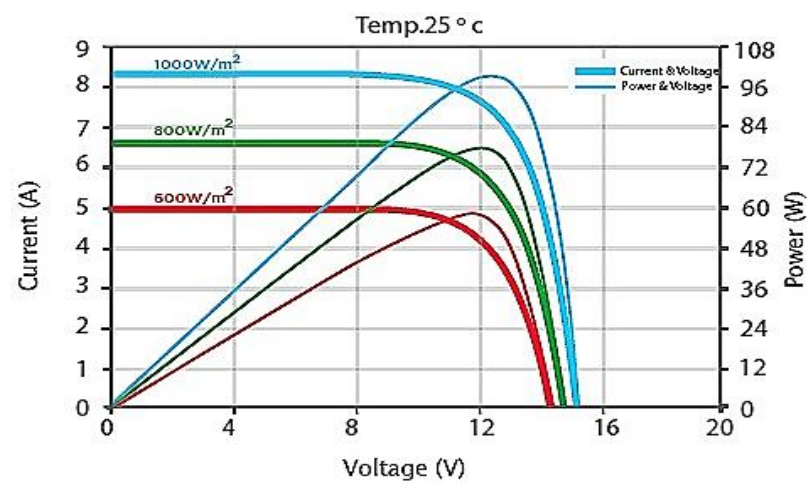

Fig.8. I-V and Power characteristics curves at different sun irradiance and loads

A suitable pressure value is attached to control the tank flow air. An axial pneumatic dc air motor is used to transform the pneumatic pressure to the required mechanical work. The dimensions of the $\mathrm{dc}$ air motor are $0.04 \mathrm{~m} 0.12 \mathrm{~m}$ for its diameter and length respectively. Finally, the rating of the dc permanent magnetic generator selected to feed the isolated resistive tungsten lamp is $3 \mathrm{~W}$, and $6 \mathrm{~V}$.

\section{B. System modeling}

During the charging process, the tank input energy $E_{\text {in }}$ can be computed using (6) [41].

$$
\mathrm{E}_{\text {in }}=\operatorname{Pr}_{\text {initTank }} \mathrm{V}_{\text {Tank }} \times \ln \frac{\text { Pr }_{\text {initTank }}}{\operatorname{Pr}_{\text {finalTank }}}
$$

where $\operatorname{Pr}_{\text {initTank }}$ and $\operatorname{Pr}_{\text {finalTank }}$ are the initial and final tank pressures, and $\mathrm{V}_{\text {Tank }}$ is the tank volume in $\mathrm{m}^{3}$. If the initial and final tank pressures are 6.5 and 1 bar respectively so the corresponding stored energy equals $1.53 \mathrm{Wh}$. The discharging process of the full storage tank is carried out experimentally. The measurements of voltages, currents, and powers are recorded instantaneously and expressed in both Table II and Figure 9.

According to the recorded experimental prototype data the discharging process takes about $70 \mathrm{sec}$. It is noted that the lamp shines at nearly constant power for about $50 \mathrm{sec}$ and its brightness falls to zero in $20 \mathrm{sec}$. The curve fitted in Figure 9, can be used to estimate the generated output energy.
The output load energy $E_{\text {out }}$ is obtained by computing the area under the load power curve and it is found to be $181 \mathrm{Ws}$. Hence, the system energy efficiency $\frac{E_{\text {out }}}{E_{\text {in }}}$ is about $3.3 \%$. It is observed that the obtained efficiency is very low, this is due to several reasons. In general, the efficiencies of small-size systems are always low [42]. There are some other practical reasons related to the tested prototype such as bad system bearings of the used dc generator, air leakage of the rubber hose, and heat leakage of the tank.

To study practically the impact of the pressure variations on the discharging time and the corresponding storage energy of the CAES system, the experimental part is implemented again several times at different pressure values and the obtained corresponding results are depicted in Figure 10.

It can be observed that both the energy stored and discharging time are increased with the increasing of the pressure tank which finally improves the overall system efficiency. It is known that the air enthalpy decreases with the increase of the pressure which leads to a decrease in air tank temperature. So, it is preferable to operate the system at highlevel pressures.

\section{ISOLATED VILLAGE CASE STUDY}

The proposed prototype can be modified and applied on a large scale to feed a specific Egyptian village (Halayeb) which is considered a good location to utilize the CAES system. The village lies near a lot of salt caverns that can be used as largesize, low-cost reservoirs for the CAES systems [43]. The expected output PV power is about $1830 \mathrm{kWh} / \mathrm{kWp}$ per year [44]. The level of sunshine can be reached at about 3870 hours per year [45-46]. The village contains about 135 homes. The average consumption of each home per day is nearly 0.336 $\mathrm{kWh}$ for lighting and $2.2 \mathrm{kWh}$ for non-lighting loads such as refrigerators, fans, TV, and washing machines. Hence, the total load per day is about $2.536 \mathrm{kWh} /$ day per home and 342 $\mathrm{kWh}$ for village loads [46- 47]

According to the proposed prototype system modeling, the estimated required stored input energy will be $10363 \mathrm{kWh} /$ day by considering low model system efficiency as mentioned before. If the operating pressure is 6.5 bar so the corresponding required storage reservoir is about $30667 \mathrm{~m}^{3}$. The storage reservoir could be represented as an underground room with dimensions $50 \times 60 \times 10 \mathrm{~m}$, but a natural cavern or salt mine is preferable for cost considerations. Surely if the cave can withstand the application of higher pressure levels, this guarantees to improve the system efficiency.

\section{A. System sizing}

The proposed system consists of a PV module, a dc compressor, a storage tank, an air motor, a dc generator, and the load. The required PV area and the peak power can be calculated by the following equations: [46]

$$
\begin{aligned}
& \mathrm{A}_{\mathrm{rPV}}=\frac{\mathrm{E}_{\mathrm{rL}}}{\mathrm{H}_{\mathrm{r}} \times \mathrm{T}_{\mathrm{rc}} \times \eta_{\mathrm{rPV}} \times \eta_{\mathrm{rC}} \times \eta_{\mathrm{rCA}}} \\
& \mathrm{P}_{\mathrm{rPV}}=\mathrm{A}_{\mathrm{rPV}} \times \eta_{\mathrm{rPV}} \times \mathrm{H}_{\mathrm{rSC}}
\end{aligned}
$$


where; $A_{r P v}, E_{r L}, H_{r}, T_{r c}, \eta_{r P V}, \eta_{r C}, H_{r S C}, P_{r P v}$, and $\eta_{\text {rCA }}$ are the total area of the required PV array, load solar energy, total daily solar energy $\left(\mathrm{kWh} / \mathrm{m}^{2} /\right.$ day $)$, cells temperature, cells efficiency, control system efficiency (94\%), rated irradiation, $\left(1 \mathrm{~kW}\right.$ per $\left.\mathrm{m}^{2}\right)$, the cells peak power, and CAES system efficiency (3.3\%) respectively

TABLE II

EXPERIMENTAL MEASUREMENTS AND CORRESPONDING POWER OF CAES SYSTEM PROTOTYPE

\begin{tabular}{l||l||l}
\multicolumn{1}{l||}{$\mathbf{~ ( A )}$} & $\mathbf{V}(\mathbf{V})$ & $\mathbf{P}(\mathbf{W})$ \\
\hline 0.51 & 6.21 & 3.2 \\
\hline 0.51 & 6.21 & 3.2 \\
\hline 0.50 & 6.21 & 3.1 \\
\hline 0.50 & 6.21 & 3.1 \\
\hline 0.50 & 6.21 & 3.1 \\
\hline 0.48 & 6.2 & 3.0 \\
\hline 0.48 & 6.2 & 3.0 \\
\hline 0.48 & 6.2 & 3.0 \\
\hline 0.47 & 6.0 & 2.8 \\
\hline 0.47 & 6.0 & 2.8 \\
\hline 0.42 & 5.5 & 2.3 \\
\hline 0.31 & 5.3 & 1.7 \\
\hline 0.15 & 3.9 & 0.5
\end{tabular}

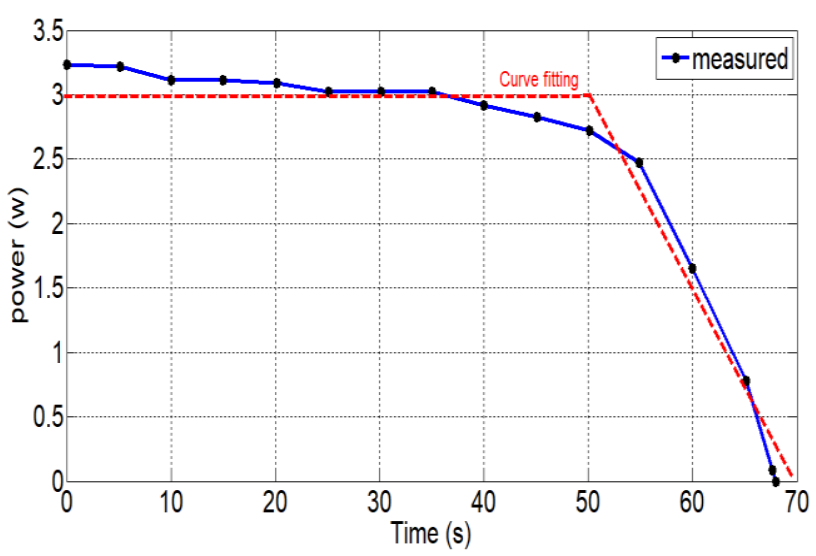

Fig.9 Variation of measured dc generator output power with time at 6.5 bar

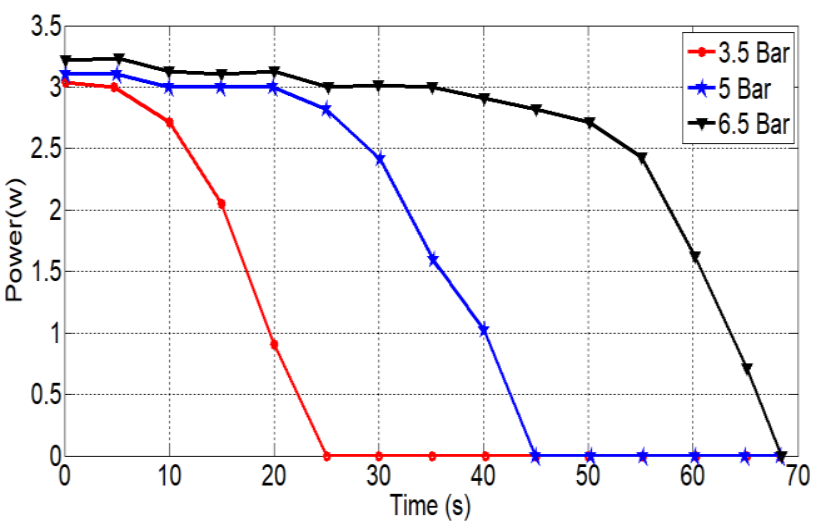

Fig.10. Variation of stored energy with tank pressure

General algorism steps for designing a CAES system supplied by PV panels are presented in Figure 11. Following are detailed design steps for the proposed system.

The PV type used in this study is the KW-SP-150M
Monocrystalline. Applying equations (7) and (8) the required cells' area is $10913 \mathrm{~m}^{2}$ [48]. Hence, the number of panels sufficient to supply the village load is 12950 panels with a total $1942.5 \mathrm{~kW}$ peak power with an overall cost of $777000 \$$.

The produced energy is stored in a pneumatic storage zone to supply the village loads all over day hours. It is preferable to share the total compressor power with identical small rating compressors that help to get more stability for the system and increases its reliability. According to the daily energy required by the village homes ( $342 \mathrm{kWh} /$ day), thirteen DC compressors are used to charge the storage zone with each rated $150 \mathrm{~kW}, 8$ bar, $200 \mathrm{~V}$. The cost of each compressor is approximately 5000 \$. A rated 6.3 bar air motor of type TMW15QD is used for discharging the tank energy. The corresponding rated torque, power, speed, and air consumption are 154.5 N.m, $31.5 \mathrm{~kW}, 1945 \mathrm{rpm}, 242.5 \mathrm{~L} / \mathrm{s}$ respectively.

To upgrade the required speed to $3000 \mathrm{rpm}$, two devices are used with a gearbox. The price of each one is about 1600 $\$$. A three-phase $45 \mathrm{~kW}, 3000 \mathrm{rpm}, 220 \mathrm{~V}$ ac synchronous permanent generator with approximately $5000 \$$ cost is used.

The generator can be used also as one machine which produces the total rated power, or the total power can be shared also between many identical machines, depending on the number of air motor devices in the system, as each air motor should be coupled with one generator.

The number of required generators depends on the number of air motor devices in the system, as each air motor should be coupled with one generator. So, one generator can be used to produces the total rated power, or a number of identical machines are used to share the load.

\section{B. Economic Study}

The operation and maintenance cost $\mathrm{OM}_{\mathrm{rc}}$ for the designed system can be determined as follows [46]:

$$
\mathrm{OM}_{\mathrm{rc}}=0.02 \times \mathrm{PV}_{\mathrm{rc}} \times\left(\frac{1+\mathrm{i}_{\mathrm{r}}}{1+\mathrm{d}_{\mathrm{r}}}\right)\left[\frac{1-\left(\frac{1+\mathrm{i}_{\mathrm{r}}}{1+\mathrm{d}_{\mathrm{r}}}\right)^{\mathrm{n}_{\mathrm{r}}}}{1-\left(\frac{1+\mathrm{i}_{\mathrm{r}}}{1+\mathrm{d}_{\mathrm{r}}}\right)}\right]
$$

WherePV $\mathrm{rc}_{\mathrm{rc}}, \mathrm{i}_{\mathrm{r}}, \mathrm{d}_{\mathrm{r}}, \mathrm{n}_{\mathrm{r}}$, are PV modules cost, inflation rate, discount rate, and life cycle period of the system respectively.

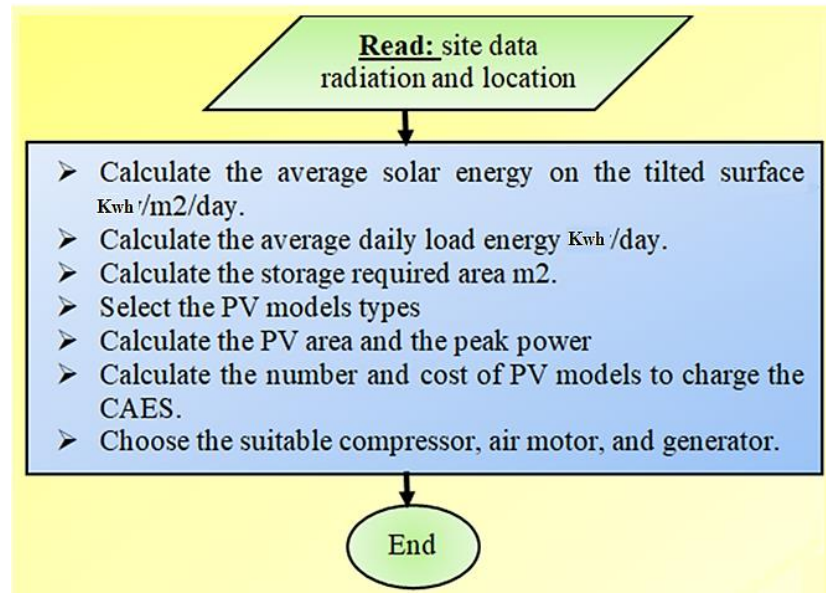

Fig.11. A general algorism steps for designing a CAES system supplied by PV panels 
The total life cycle cost LCC $_{r}$ is determined by (10).

$\mathrm{LCC}_{\mathrm{r}}=\mathrm{PV}_{\mathrm{rc}}+\mathrm{CO}_{\mathrm{rc}}+\mathrm{AM}_{\mathrm{rc}}+\mathrm{G}_{\mathrm{rc}}+\mathrm{C}_{\mathrm{rc}}+\mathrm{I}_{\mathrm{rc}}+\mathrm{OM}_{\mathrm{rc}}$

where $\mathrm{CO}_{\mathrm{rc}}, \mathrm{AM}_{\mathrm{rc}}, \mathrm{G}_{\mathrm{rc}}, \mathrm{C}_{\mathrm{rc}}, \mathrm{I}_{\mathrm{rc}}$ are the compressor cost, air motor cost, generator cost, controller cost, and installation cost respectively.

The annual life cycle cost ALCC $_{r}$ is computed as [49-50];

$$
\mathrm{ALCC}_{\mathrm{r}}=\operatorname{LCC}_{\mathrm{r}}\left[\frac{1-\left(\frac{1+\mathrm{i}_{\mathrm{r}}}{1+\mathrm{d}_{\mathrm{r}}}\right)}{1-\left(\frac{1+\mathrm{i}_{\mathrm{r}}}{1+\mathrm{d}_{\mathrm{r}}}\right)^{\mathrm{n}_{\mathrm{r}}}}\right]
$$

So, the cost of one unit of energy $\mathrm{UC}_{\mathrm{r}}$ in $\$ / \mathrm{kWh}$ is given by [51];

$$
U C_{r}=\frac{A L C C_{r}}{365 \mathrm{E}_{\mathrm{rL}}}
$$

A summary of the system cost is presented in Table III. From the obtained results, it is obvious that the proposed system can feed the load of the village under study with a total cost reached to $1,318,324 \$$ at CAES system efficiency $3.3 \%$ and $132,812 \$$ at efficiency $70 \%$ for 25 years' lifetime.

TABLE III

\begin{tabular}{|c|c|c|}
\hline ELEMENT & $\begin{array}{l}\text { Cost }(\$) \\
\eta_{\mathrm{rCA}}=3.3 \%\end{array}$ & $\begin{array}{l}\text { Cost }(\$) \\
\eta_{\mathrm{rCA}}=70 \%\end{array}$ \\
\hline$P V$ & 777,000 & 37,200 \\
\hline Controller & $\begin{array}{l}194,250 \\
(25 \% \text { of PV cost) }\end{array}$ & 9,300 \\
\hline DC compressor & 65,000 & 65,000 \\
\hline Air motor & 3,200 & 3,200 \\
\hline Generator & 5,000 & 5,000 \\
\hline$O \& M$ cost & $\begin{array}{l}196,174 \\
(2 \% \text { of PV cost) }\end{array}$ & 9,392 \\
\hline Installation cost & $\begin{array}{l}77,700 \\
(10 \% \text { of PV cost) }\end{array}$ & 3,720 \\
\hline$L C C_{r}$ & $1,318,324$ & 132,812 \\
\hline$A L C C_{r}$ & 99,827 & 10,056 \\
\hline$U C_{r}$ & $0.8 \quad \$ / \mathrm{kWh}$ & $0.08 \$ / \mathrm{kWl}$ \\
\hline
\end{tabular}
SYSTEM COST SUMMARY

\section{Conclusion}

CAES is a high-rating energy storage system, it can store huge amounts of energy besides it runs for a long lifetime. CAES system is not only friendly to the environment but also has a low maintenance cost.

Two new and different CAES models were proposed. The first model included a wind turbine, compressor, with selected rating values as $220 \mathrm{MW}, 200 \mathrm{MW}$, and a storage reservoir with a volume of $150,000 \mathrm{~m} 3$. The model was simulated efficiently in dynamic mode. The effectiveness of the proposed model was investigated and proven by simulating a small CAES power system integrated with $5 \mathrm{~kW}$ isolated load fed by Bergey Excel-S $10 \mathrm{~kW}$ wind turbine. The second proposed CAES model was a laboratory-scale prototype supplied from a PV panel using a dc compressor. The experimental system succeeded to store $1.53 \mathrm{Wh}$ of energy in a specified tank and supplied a connected load. The small size systems' efficiencies are normally low but they can be increased for large-scale systems. A proposed case study was suggested to supply an off-grid isolated Egyptian village. A general algorism for designing a CAES system supplied by PV panels was presented. A simple economic analysis to calculate the total cost of feeding the village with the proposed CASEPV system was presented. The study showed the capability of the proposed system to supply a peak domestic load of 340 $\mathrm{W} /$ home for a base load of $100 \mathrm{~W}$. The average value of electricity consumption of 135 homes with the same characteristics is $342 \mathrm{kWh} /$ day, which costs $1,318,324 \$$ at $3.3 \%$ system efficiency and $132,812 \$$ at $70 \%$ system efficiency for a lifetime of 25 years. The total costs are expected to decrease in the near future due to foreseeable technology development.

The importance of this study indicates briefly the capability of the proposed models to be applied for any given power system with any CAES size (small or large).

\section{Authors Contribution}

Author 1 did the following:

1. Research idea development

2. Suggest the Methodology

3. Permanent Supervision

4. Review the proposed model and the computer program

5. Data analysis and interpretation

6. Project administration

7. Provide the required resources

8. Edit and critical review of the article

\section{Author 2 did the following:}

1. Data collection and tools

2. Data analysis and interpretation

3. Apply the Methodology

4. Write the Software program

5. Drafting the article

Author 3 did the following:

1. Research idea development

2. Review the Methodology

3. Permanent Supervision

4. Project administration

5. Final approval of the version to be published

The corresponding author is responsible for ensuring that the descriptions are accurate and agreed upon by all authors.

\section{REFERENCES}

[1] X. Luo, J. Wang, M. Dooner, and J. Clarke, "Overview of current development in electrical energy storage technologies and the application potential in power system operation", Applied Energy, vol. 137, 2015, pp 511-536.

[2] S. Rehman, L. Al-Hadhrami, and M. Alam. "Pumped hydro energy storage system: A technological review." Renewable and Sustainable Energy Reviews vol. 44 2015: pp. 586-598. 
[3] H. Ferreira, R. Garde, G. Fulli, W. Kling and J. Lopes, "Characterisation of electrical energy storage technologies", Energy, vol. 53, 2013, pp. 288-298.

[4] R. Madlener and J. Latz, "Economics of centralized and decentralized compressed air energy storage for enhanced grid integration of wind power", Applied Energy, vol. 101, 2013, pp. 299-309.

[5] A. Hassan "Egypt: Electricity outages spoil Ramadan celebrations", Available at:

http://latimesblogs.latimes.com/babylonbeyond/2010/08/egypt-

electricity-outages-spoil-ramadan-celebrations.html [Accessed: 04- Feb2018].

[6] F. Crotogino F, K. Mohmeyer, R. Scharf, "Huntorf CAES: More than 20 years of successful operation", SMRI Spring Meeting; 2001, Orlando, FL, USA, 23-24 April 2001, p. 351-357.

[7] A. Sciacovelli, et al. "Dynamic simulation of Adiabatic Compressed Air Energy Storage (A-CAES) plant with integrated thermal storage-Link between components performance and plant performance." Applied Energy, vol. 185, part 1, Jan. 2017: pp. 16-28.

[8] H. Ibrahim, A. Ilinca and J. Perron, "Energy storage systemscharacteristics and comparisons", Renewable and Sustainable Energy Reviews, vol. 12, no. 5, 2008, pp. 1221-1250.

[9] A. Rogers, et. al., "Compressed air energy storage: Thermodynamic and economic review", IEEE PES General Meeting Conference \& Exposition, National Harbor, MD, USA, 27-31 July 2014, pp. 1-5.

[10] G. Kleiser, V. Rauth, "Dynamic modelling of compressed air energy storage for small-scale industry applications", International Journal of Energy Engineering, vol. 3 No. 3, 2013, pp. 127-137

[11] H. Ibrahim, K. Belmokhtar and M. Ghandour, "Investigation of usage of compressed air energy storage for power generation system improving Application in a micro-grid integrating wind energy", Energy Procedia, vol. 73, 2015, pp. 305-316.

[12] M. Raju and S. Kumar Khaitan, "Modeling and simulation of compressed air storage in caverns: A case study of the Huntorf plant", Applied Energy, vol. 89, no. 1, 2012, pp. 474-481.

[13] J. Greenblatt, et. al., "Base load wind energy: modeling the competition between gas turbines and compressed air energy storage for supplemental generation", Energy Policy, vol. 35, no. 3, 2007, pp. 14741492

[14] N. Hartmann, et. al., "Simulation and analysis of different adiabatic compressed air energy storage plant configurations", Applied Energy, vol. 93,2012 , pp. 541-548.

[15] H. Bitaraf and S. Rahman, "Reducing curtailed wind energy through energy storage and demand response", IEEE Transactions on Sustainable Energy, vol. 9, no. 1, Jan. 2018, pp. 228-236,

[16] L. Chen, et. al., "A novel isobaric adiabatic compressed air energy storage (IA-CAES) system on the base of volatile fluid", Applied Energy, vol. 210, 2018, pp. 198-210.

[17] Y. Mazloum, H. Sayah, and M. Nemer, "Dynamic modeling and simulation of an Isobaric Adiabatic Compressed Air Energy Storage (IA-CAES) system", Journal of Energy Storage, vol. 11, 2017, pp. 178190.

[18] C. Krupke, et. al., "Modeling and experimental study of a wind turbine system in hybrid connection with compressed air energy storage," IEEE Transactions on Energy Conversion, vol. 32, no. 1, March 2017, pp. 137-145.

[19] R. Rownak et, al., "Solar-Biomass-CAES hybrid system: proposal for rural commercial electrification in Bangladesh", International Journal of Innovation and Applied Studies, vol. 19, no. 3, February 2017, pp. 556571.

[20] R. Cazzaniga, et al., "Compressed air energy storage integrated with floating photovoltaic plant", Journal of Energy Storage, vol. 13, 2017, pp. 48-57.

[21] P. Joong-kyoo et. al., "Analysis, fabrication, and testing of a liquid piston compressor prototype for an Ocean Compressed Air Energy Storage (OCAES) system", Marine Technology Society Journal, vol. 48, no. 6, Dec. 2014, pp. 86-97.

[22] W. He et. al., "Study of cycle-to-cycle dynamic characteristics of adiabatic compressed air energy storage using packed bed thermal energy storage", Energy, vol. 141, 2017, pp. 2120-2134.

[23] S. Succar, R. Williams "Compressed air energy storage: theory, resources, and applications for wind power", Princeton Environmental Institute report, Princeton University, 8 April 2008.

[24] C. Bullough, et al., "Advanced adiabatic compressed air energy storage for the integration of wind energy", Proceedings of the European Wind
Energy Conference, (EWEC 2004), London UK, 22-25 November 2004, pp. 22-25.

[25] I. Calero, C. A. Cañizares and K. Bhattacharya, "Compressed Air Energy Storage System Modeling for Power System Studies," in IEEE Transactions on Power Systems, vol. 34, no. 5, pp. 3359-3371, Sept. 2019, DOI: 10.1109/TPWRS.2019.2901705.

[26] L. F. Pastuch, R. F. Coelho, T. B. Lazzarin and M. A. Salvador, "Small Scale Compressed Air Energy Storage (SS-CAES) Strategies Overview," IEEE $15^{\text {th }}$ Brazilian Power Electronics Conference and $5^{\text {th }}$ IEEE Southern Power Electronics Conference (COBEP/SPEC), Santos, Brazil, 1-4 Dec. 2019, pp. 1-6, DOI: 10.1109/COBEP/SPEC44138.2019.9065744.

[27] C. Li et al., "Mathematical Modelling of Large-Scale Compressed Air Energy Storage Systems," 2019 25th International Conference on Automation and Computing (ICAC), Lancaster, UK, 2019, pp. 1-6, DOI: 10.23919/IConAC.2019.8894979.

[28] Widjonarko et al, "Design of Air Motor Speed Control System for Small Scale Compressed Air Energy Storage Using Fuzzy Logic", International Conference on Mechanical Engineering Research and Application, Malang, Indonesia, 23-25 October 2018

[29] M. King, A. Jain, R. Bhakar, J. Mathur, J. Wang, "Overview of current compressed air energy storage projects and analysis of the potential underground storage capacity in India and the UK", Renewable and Sustainable Energy Reviews, Volume 139, 2021, 110705, ISSN 13640321, https://doi.org/10.1016/j.rser.2021.110705.

[30] S. Chen, T. Zhu, et al. "Optimization of Operation Strategies for a Combined Cooling, Heating and Power System based on Adiabatic Compressed Air Energy Storage". J. Thermal Sci., vol. 29, 2020, pp. 1135-1148. https://doi.org/10.1007/s11630-020-1170-0

[31] P. Wang, P. Zhao, J. Wang, Y. Dai, "Performance evaluation of a combined heat and compressed air energy storage system integrated with ORC for scaling up storage capacity purpose," Energy, Elsevier, vol. 190, Jan. 2020. https://doi.org/10.1016/j.energy.2019.116405

[32] E. Jannelli, et. al, "A small-scale CAES (compressed air energy storage) system for stand-alone renewable energy power plant for a radio base station: A sizing-design methodology", Energy, vol. 78, 2014, pp. 313322.

[33] P. Zhao, Y. Dai, and J. Wang, "Design and thermodynamic analysis of a hybrid energy storage system based on A-CAES (adiabatic compressed air energy storage) and FESS (flywheel energy storage system) for wind power application", Energy, vol. 70, June 2014, pp. 674-684.

[34] T.B. Ferguson, "The Centrifugal Compressor Stage", London Butterworth 1963

[35] T. Das, V. Krishnan, Y. Gu, and J. D. McCalley, "Compressed Air Energy Storage: State Space Modeling and Performance Analysis", IEEE Power and Energy Society General Meeting, Detroit, USA, 24-28 July 2011

[36] M. Moran, H. Shapiro, B. Munson, and D. Dewitt, "Introduction to Thermal Systems Engineering” John Wiley \& Sons, Inc, Sep.2002

[37] EPRI-DOE Handbook of Energy Storage for Transmission and Distribution Applications, 2003

[38] H. S. Nejad, T. Iqbal and J. Quaicoe, "Compressed Air Energy Storage System Control and Performance Assessment Using Energy Harvested Index", Electronics 2014, 3, 1-21; doi:10.3390/electronics3010001

[39] H. Ibrahim, K. Belmokhtara M. Ghandourb, "Investigation of usage of compressed air energy storage for power generation system improving Application in a microgrid integrating wind energy", Energy Procedia, vol. 73, June 2015, pp. 305-316.

[40] D. Lefebvre and F. Tezel, "A review of energy storage technologies with a focus on adsorption thermal energy storage processes for heating applications", Renewable and Sustainable Energy Reviews, vol. 67, 2017, pp. 116-125.

[41] A. Pimm, "Analysis of flexible fabric structures". Ph. D. Thesis submitted to Department of Mechanical, Materials and Manufacturing Engineering, University of Nottingham, UK, 2011.

[42] K. Herriman, "Small compressed air energy storage systems", M. Sc. Thesis submitted to School of Mechanical and Electrical Engineering, University of Southern Queensland, 2013.

[43] https://anfarabic.com/l-1m/ [Accessed: 26- Jun- 2018]. In Arabic.

[44] "Global Solar Atlas", [Online]. Available: http://globalsolaratlas.info/ [Accessed: 26- Jun- 2018].

[45] Average monthly weather in Aswan, Egypt, Available: https://weatherand-climate.com/average-monthly-Rainfall-Temperature-Sunshine, Aswan, Egypt [Accessed: 22- Jul- 2018]. 
[46] E. T. El Shenawy, A. H. Hegazy, and M. Abdellatef, "Design and Optimization of Stand-alone PV System for Egyptian Rural Communities", International Journal of Applied Engineering Research, vol. 12 , no. 20,2017 , pp. 10433-10446

[47] J. Cofré-Toledo, D. Vasco, C. Isaza-Roldán and J. Tangarife, "Evaluation of an integrated household refrigerator evaporator with two eutectic phase-change materials", International Journal of Refrigeration, vol. 93, September 2018, pp. 29-37.

[48] N. Agarwal and A. Kumar, Varun, "Optimization of grid-independent hybrid PV-diesel-battery system for power generation in remote villages of Uttar Pradesh, India", Energy for Sustainable Development, vol. 17, issue 3, June 2013, pp. 210-219.

[49] "Discount Rates", Central bank of Egypt [Online]. Available: http://www.cbe.org.eg/en/EconomicResearch/Statistics/Pages/Discount Rates.aspx [Accessed: 22- Jul- 2018].

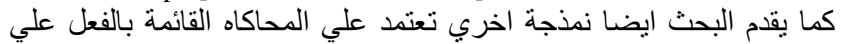

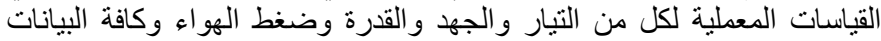

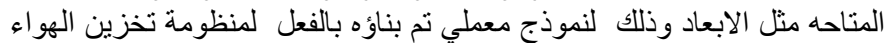

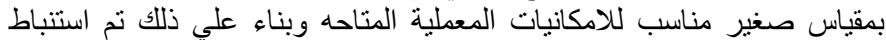
نموذج عام للتصميم يمكن تطبيقه في حالات أخري ذات مقايس وشروط لنّات تشغيل مختلفه.

وقد تم تطبيق المنهجيه المقترحه و المتبعه في النموذج الاخير علي در اسة حالة

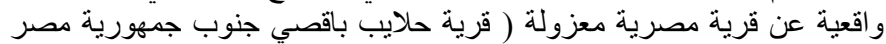

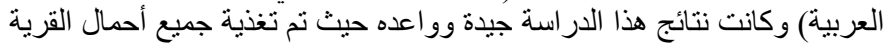

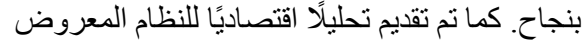

[50] A. Ghafoor and A. Munir, "Design and economics analysis of an offgrid PV system for household electrification", Renewable and Sustainable Energy Reviews, vol. 42, February 2015, pp. 496-502

[51] E. Tarigan and L. Purba, "Assessment of PV power generation for household in Surabaya using solar GIS-PV Planner simulation", Energy Procedia, vol. 47, 2014, pp. 85-93.

\section{Title Arabic:}

دراسة عملية واقتصادية لمنظومة قوي كهربية هجينه تتكون من وسيلة تخزين

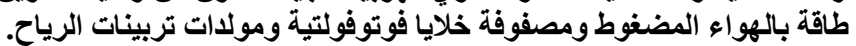

\section{Arabic Abstract:}

يقدم هذا البحث نمذجة وتنفيذ لنموذج معملي تجريبي لوسيلة تخزين الطاقة

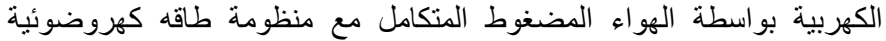

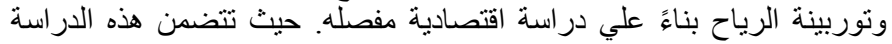

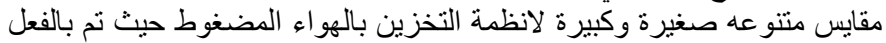

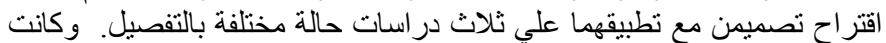

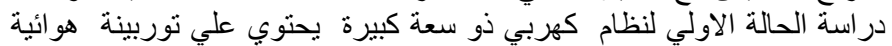

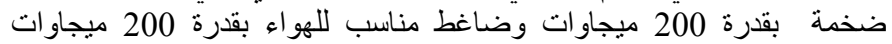

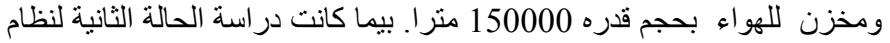

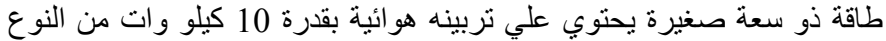

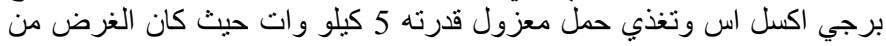

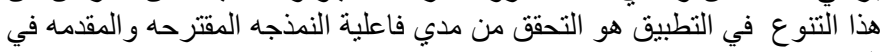

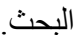

